\title{
First record of the association of the weevil Loncophorus longinasus with the fruit of munguba, Pseudobombax munguba in Central Amazonia, Brazil
}

\author{
Stefan Friedrich KEPPLER ${ }^{1 * \mathbb{D}}$, Neliton Marques da SILVA² \\ 1 Universidade Federal do Amazonas, Centro de Ciências Ambientais, Programa de Pós Graduação em Ciências Ambientais e Sustentabilidade na Amazônia, Av. \\ General Rodrigo Octavio Jordão Ramos 1200, Coroado I, 69067-005 Manaus - AM, Brazil \\ 2 Universidade Federal do Amazonas, Faculdade de Ciências Agrárias, Laboratório de Entomologia e Acarologia Agrícola, Av. General Rodrigo Octavio Jordão Ramos \\ 1200, Coroado I, 69067-005 Manaus - AM, Brazil \\ * Corresponding author: sfkeppler@yahoo.com; iD https://orcid.org/0000-0001-6227-163X
}

\begin{abstract}
We report the first record of occurrence of Loncophorus longinasus in fruits of munguba, Pseudobombax munguba, in the state of Amazonas, Brazil. Some morphological and biological aspects of L. longinasus are presented. Adults were obtained through natural emergence from munguba fruits that opened for seed dispersal. The fruits had perforations leading to galleries through the exocarp. Inside the fruit, larvae were found at the seed insertion points on the central seed attachment structure. The pupae developed in a cocoon at the same structure and turned mature simultaneously with the capsule opening. Together with the larvae, the presence of ants (Pseudomyrmex sp.) was observed, that apparently maintained the galleries open for access and feeding on larval exudates.
\end{abstract}

KEYWORDS: Insecta, Curcilionidae, immature, Malvaceae, ants, Pseudomyrmex

\section{Primeiro registro da associação do gorgulho Loncophorus longinasus ao fruto de munguba, Pseudobombax munguba, na Amazônia Central, Brasil}

\section{RESUMO}

Este é o primeiro registro de ocorrência de Loncophorus longinasus em frutos da árvore munguba, Pseudobombax munguba, no Estado do Amazonas, Brasil. Alguns aspectos morfológicos e biológicos de L. longinasus são apresentados. Adultos foram obtidos quando emergiam naturalmente durante a abertura do fruto da munguba para a dispersão das sementes. Os frutos apresentaram perfuraçóes que formavam galerias através do exocarpo. Dentro do fruto, foram encontradas larvas em pontos de inserção de sementes na estrutura central. Pupas foram encontradas em casulos na mesma estrutura central, e se transformaram em adultos simultaneamente com a abertura da cápsula. Junto às larvas, detectamos a presença de formigas (Pseudomyrmex sp.), que possivelmente mantêm abertas as galerias no exocarpo para acesso e consumo dos exsudatos das larvas.

PALAVRas-CHAVE: Insecta, Curculionidae, imaturos, Malvaceae, formigas, Pseudomyrmex

Munguba, Pseudobombax munguba (Mart. \& Zucc.) Dugand. (Malvaceae, Bombacoidae), is a common tree in Central Amazonia. It has a green bark and red, oviform fruit-capsules. The capsules burst spontaneously when dried and release a cotton-like material (Gribel and Gibbs 2002) composed of fine natural fibers which disperse the seeds by wind and water current. These very light fibers are hollow, hydrophobic and have thermoacoustic insulation properties similar to the material produced by the kapok tree, Ceiba pentandra (L.) Gaertn., known in Brazil as samaúma. Because of its extreme flood-tolerance, P. munguba can be used in reforestation programs, particularly in areas with a mild drought period (Marenco et al. 2019).
Loncophorus Chevrolat, 1832, (Coleoptera, Curculionidae) is a neotropical beetle genus with 14 species, distributed from Mexico to Argentina (Clark 1995). Most species are associated with trees of the family Malvaceae, subfamily Bombacoidea (former Bombacaceae) (Clark and Burke 1986). Larvae of some species of Loncophorus are known to develop in fruits, others in flower buds (Clark 1988). Vanin et al. (2013) presented a detailed description of immatures (larvae and pupae) of Loncophorus pustulatus (Champion 1903) in flowers of Ceiba speciosa (A. St.-Hil.) Ravenna.

Loncophorus longinasus Costa Lima, 1955, was described from its type locality in Fonte Boa, in the state of Amazonas, 
northern Brazil (Costa Lima 1955). Other specimens were collected along the central Amazonian floodplains. A line drawing of this species with its expressive proboscis was used as cover image by Costa Lima (1956). Costa Lima (1955) argued that the larvae of $L$. longinasus might be found in fruit of Bombacaceae. So far, however, no association to a host plant had been reported for L. longinasus. Also, the sexual dimorphism in this species, as presented by Clark (1988), is not conclusive, because of the very different sampling areas of males and females.

Our observations were made on fruits of $P$. munguba collected in the locality of Paraíso D'Ângelo, in the

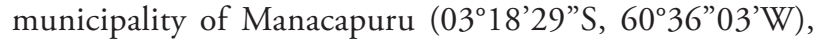
Amazonas state, Brazil. We collected 15 fruits to harvest fruit fibers, from a variety with globose, dark-red fruits. The tree was about $12 \mathrm{~m}$ high. The collected capsules were stored and transported in woven sacs, and were then placed in an open, ventilated and insolated area to dry out for bursting and subsequent fiber extraction. After the capsules opened, the entire fruit content was stored in black open 50-liter black plastic bags for further drying and seed separation.

The fruit of P. munguba are 20 to $30 \mathrm{~cm}$ long and 15 to 18 $\mathrm{cm}$ in diameter (Fern 2014). In the fruits in our sample, the central seed attachment structure was covered by a 2 to $3-\mathrm{cm}$ thick mantle of condensed fibers, covered by a hard leathern exocarp 1.5 to $1.8 \mathrm{~cm}$ thick, forming a heavy shell composed of five to seven longitudinal elements. Ten of the 15 fruits presented one to 11 perforations with an initial white, $3-\mathrm{cm}$ wide, circular depression (Figure 1), ending in a small hole of almost $0.5 \mathrm{~mm}$ in diameter. This hole led to a gallery through the entire exocarp and through the cob of condensed fibers. At the inner side of the capsule shell, calli were formed around the end of the galleries. In three fruits, while pulling out the central seed atachment structure to scrape off the fruit-fibers, one of the authors (SFK) noticed five brown cocoons with pupae and 12 white curculioniform larvae (overall for the three fruits) placed at seed attachment points to the central structure (Figure 2), actually having displaced some seeds (Figure 2a). No further quantification of larvae and pupae was carried out at the time. When fully developed, the larvae measured about $12 \mathrm{~mm}(\mathrm{n}=12)$ in length. The pupae produced a thin, but resistant cocoon of compacted fibers (Figure $2 b$ ).

A few minutes after the fibers had been stored in plastic bags, it was observed that adult beetles flew out. Some of the adults had a plump flight, because of their long proboscis, longer than their body length. A couple of adults, that were identified as weevils, and larvae were fixed in $70 \%$ ethanol and sent to Universidade de of São Paulo for species identification by Dr. Sergio Vanin, an expert for Curculionidae, who identified the specimens as Loncophorus longinasus.

We observed sexual dimorphism in the adults (Figure 3), as had been proposed by Clark (1988). Male body-length was

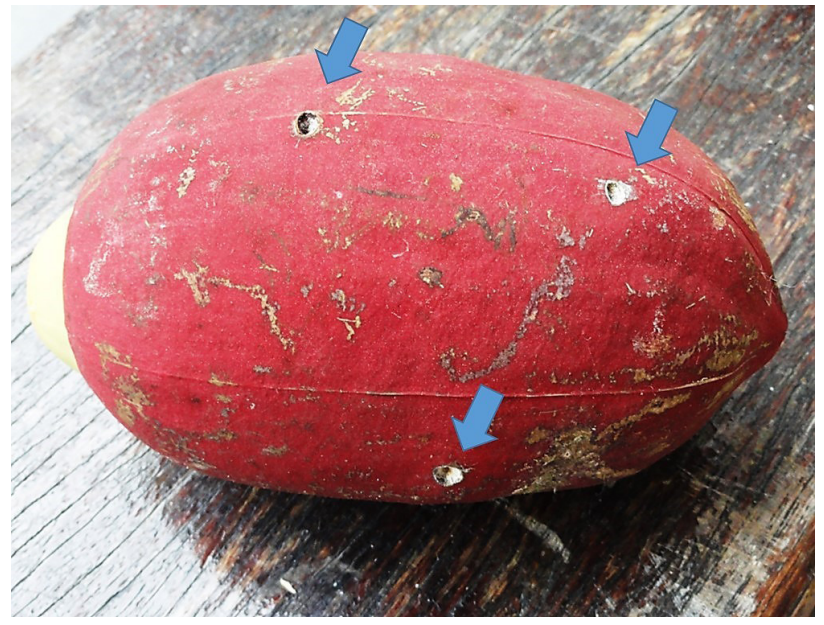

Figure 1. Fruit of Pseudobombax munguba that contained immatures of Loncophorus longinasus, showing the perforations in the exocarp (arrows). This figure is in color in the electronic version.

$13.3 \pm 0.2 \mathrm{~mm}(\mathrm{n}=10)$ with a proboscis length nearly half of the body (Figure 3a,b). Females had about the same body length $(13.5 \pm 0.4 \mathrm{~mm}, \mathrm{n}=5)$, but a proboscis measuring about 1.5 of their body length (Figure $3 c, d$ ). The recently emerged adult males and females of $L$. longinasus in our sample had larger body size and minor morphological differences relative to the description of specimens by Clark (1988), which was based on males from different localities. The elytra in both sexes in our sample were striated and contained six irregular spots of brown bristles, located in the frontal, medial and distal regions of the elytra (Figure 3a,c). The brownish color of the males of $L$. longinasus in our sample appeared very similar to that of $L$. pustulatus, as photographed and described by Vanin et al. (2013) (the female of $L$. pustulatus has not been described so far). This close similarity could have led Clark (1988) to describe males of other species as $L$. longinasus. The larvae in the munguba fruit also looked very similar to the larvae of L. pustulatus, as drawn and described by Vanin et al. (2013).

We also observed the presence of tachi ants (Pseudomyrmex Lund 1831) coming out of the perforations on the fruit outer surface (Figure 1). These ants are commonly associated with P. munguba (Ward 1999). The ants smeared the fibers with the sap released by the larvae. Whether the galleries originate from the boreholes of $L$. longinasus or were made by the ants themselves remains unclear. The emergence of adults occured immediately after fruit opening, allowing them to leave the fruit. The thick and hard wall of the capsule of mature fruits suggests that the perforation for egg insertion may occur at the initial stage of fruit development, as is known from Curculio glandium and Curculio nucum (Costa Lima 1956).

This is the first record of $L$. longinasus associated with fruits of $P$. munguba fruit. So far, the occurrence of $L$. longinasus larvae in this fruit seems to be rare, maybe being 

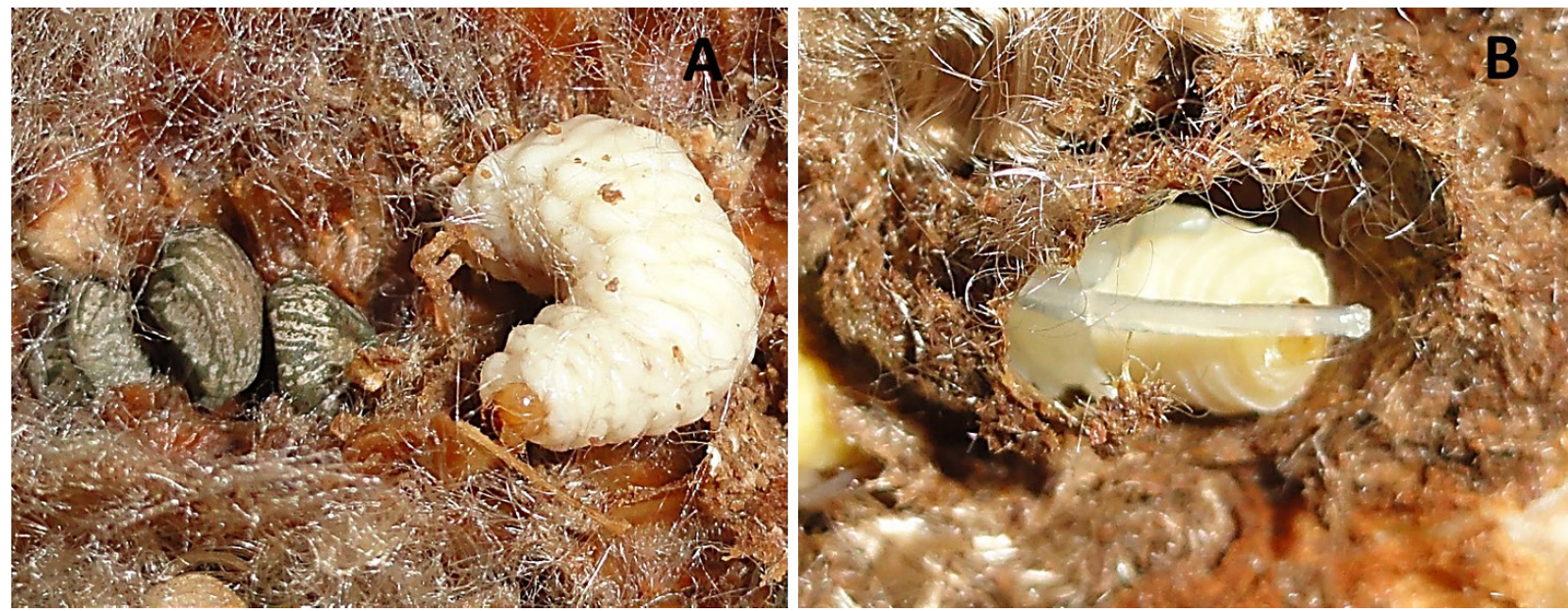

Figure 2. Loncophorus longinasus in a fruit of Pseudobombax munguba; A - Larva at the point of seed insertion; B - Pupa with long proboscis at the central seed attachment structure. This figure is in color in the electronic version.
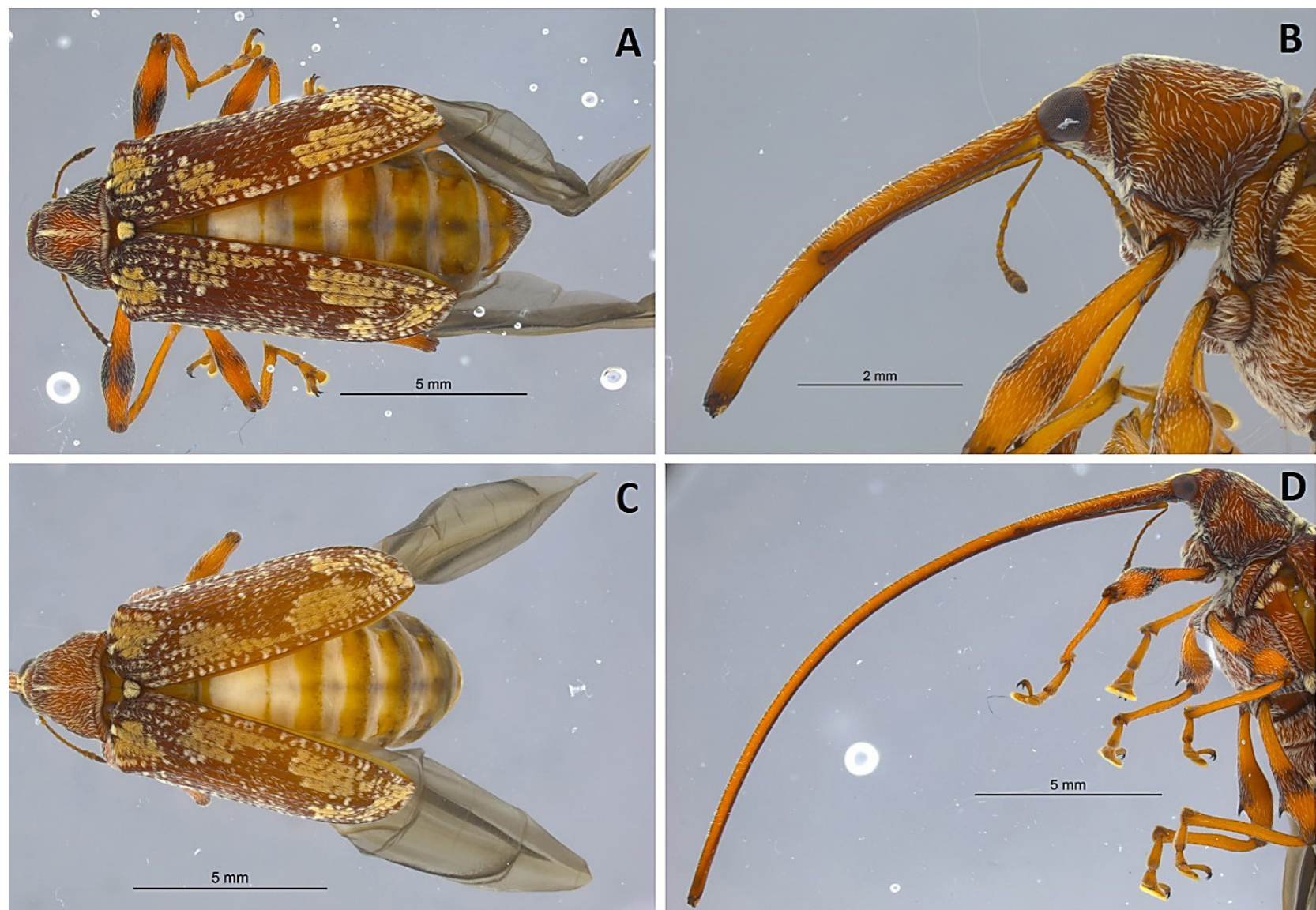

Figure 3. Sexual dimorphism of adult Loncophorus longinasus. A and B - male; C and D - female; A and C - dorsal view (elytra with six brown spots); B and D - lateral view (showing proboscis length). The animals were captured when emerging from the dried-out munguba fruit content. This figure is in color in the electronic version.

restricted to the examined variety. However, the presence of the weevil should be monitored when planting $P$. munguba in monoculture for commercial fruit-fiber production, as larvae of L. longinasus may become a threat to product quality.

\section{ACKNOWLEDGMENTS}

We thank the Fundação de Amparo de Pesquisa do Amazonas - FAPEAM for the doctorate scholarship to SFK, and Dr. Ruth Keppler and Léo Rossy Ribeiro of the Laboratory 
for Cytotaxonomy of Aquatic Insects of Instituto Nacional de Pesquisas da Amazônia - INPA for the photographs. We are also grateful to Prof. Dr. Sérgio Antônio Vanin of the Institute of Biosciences of Universidade de São Paulo - USP for the identification of the specimens of Loncophorus longinasus.

\section{REFERENCES}

Clark, W.E. 1988. Revision of the Weevil Genus Loncophorus Chevrolat (Coleoptera: Curculionidae: Anthonominae). Quaestiones Entomologicae, 24: 465-520.

Clark, W.E. 1995. A new species of Loncophorus from Mexico (Coleoptera: Curculionidae, Anthonomini) associated with Mortoniodendron (Malvales: Tiliaceae). Anales del Instituto Biologico de la Universidad Nacional Autónoma de Mexico, Serie Zoologia, 66: 107-112.

Clark, W.E.; Burke, H.R. 1986. A new Neotropical species of Anthonomus (Coleoptera: Curculionidae) associated with Bombacopsis quinata (Bombacaceae). Proceedings of the Entomological Society of Washington, 88: 320-327.

Costa Lima, A.M. 1955. Sobre as espécies de Loncophorus (Col. Cure. Anthonominae). Neotropica, 1: 50-54.

Costa Lima, A.M. 1956. Insetos do Brasil. $10^{\circ}$ Tomo, Capítulo XXIX. Coleopteros. 2a Parte. Série Didatica no 12 . Escola Nacional de Agronomia, Rio de Janeiro, 373p.
Fern, K. 2014. Useful Tropical Plants Database: Pseudobombax munguba. Available at: (http://tropical.theferns.info/ viewtropical.php?id=Pseudobombax+munguba). Accessed on 29 May 2019.

Gribel, R.; Gibbs, P.E. 2002. High outbreeding as a consequence of selfed ovule mortality and single vector bat pollination in the Amazonian tree Pseudobombax munguba (Bombacaceae), International Journal of Plant Sciences, 163: 1035-1043.

Marenco, R.A.; Sousa, F.F.; Oliveira, M.F. 2019. Leaf phenology, growth and photosynthesis in Pseudobombax munguba (Malvaceae). Revista Ceres, 66: 001-010.

Vanin, S.A.; Bená, D.C.; Albertoni, F.F. 2013. Description of immatures and natural history of the weevil Loncophorus pustulatus (Champion 1903) (Coleoptera: Curculionidae: Curculioninae) associated with flowers of Ceiba speciosa (A. St.Hil.) Ravenna (Bombacoidea: Malvaceae) in southeast Brazil. Zootaxa, 3636: 451-462.

Ward, P.S. 1999. Systematics, biogeography and host plant associations of the Pseudomyrmex viduus group (Hymenoptera: Formicidae), Triplaris - and Tachigali -inhabiting ants. Zoological Journal of the Linnean Society, 126: 451-540.

RECEIVED: $15 / 07 / 2019$

ACCEPTED: $27 / 10 / 2019$

ASSOCIATE EDITOR: Pitágoras C. Bispo 